\title{
Hydrographic features of Magellan and Fuegian inland passages and adjacent Subantarctic waters*
}

\author{
TARSICIO ANTEZANA \\ Departamento de Oceanografía, Universidad de Concepción, Concepción, Chile. E-mail: antezana@udec.cl
}

\begin{abstract}
SUMMARY: Hydrographic features and bottom profiles along the main passages from Paso Ancho in the Straits of Magellan to the Beagle Channel and those of adjacent oceanic waters are examined with regard to water origin and circulation. Sills and shallow entrances likely limited water exchange. Adjacent oceanic waters were warmest in the Atlantic and saltiest in the Pacific sectors. Waters within the inland passages were fresher and cooler than open shelf waters, showing a decreasing salinity gradient between the Beagle Channel and the Straits of Magellan and a subsurface wedge of warmest and saltiest oceanic water underneath a core of cold and brackish water in Brazo Noroeste. Subsurface water masses of the Straits of Magellan and Brazo Noroeste seem to be entrapped. Temperature and density distributions suggest that the inflow of salty and warm Pacific waters takes place through Bahía Cook. Westward and northward toward the Straits of Magellan, these waters may progressively mix with cooler and more brackish waters adjacent to Cordillera de Darwin. In this sector (Canal Brecknock-Canal Cockburn) stratification of the water column was weaker and became zero toward the Straits of Magellan (Seno Magdalena / Paso Ancho). Distribution of water properties was consistent with bathymetry profiles and suggests the following subdivision of microbasins along the Magellan-Beagle passage: 1.- Paso Ancho-Seno Magdalena, 2.Canal Magdalena-Canal Brecknock, 3.- Canal Ballenero-Brazo Noroeste, 4.- Beagle Channel .
\end{abstract}

Key words: Hydrography, bathymetry, straits, microbasins, estuaries, fjords, brackish, glacier waters.

RESUMEN: RASGOS HIDROGRÁFICOS DE LOS CANALES INTERIORES MAGALLÁNICOS Y FUEGUINOS Y DE LAS AGUAS SUBANTÁRTICAS ADYACENTES. - Las características hidrográficas y los perfiles batimétricos a lo largo del transecto Estrecho de Magallanes a Canal del Beagle se examinaron en relación al origen y circulación de las aguas. Las aguas oceánicas adyacentes fueron más cálidas en el Atlántico y más salinas en el Pacífico. El intercambio de agua parece limitado por bajos y pasos someros. Las aguas interiores fueron más salobres y frías que las aguas oceánicas de la plataforma, presentando una disminución gradual de la salinidad desde el Canal del Beagle al Estrecho de Magallanes y una cuña subsuperficial de agua más caliente y salina por debajo de un núcleo de agua fría y salobre en el Brazo Noroeste. Las aguas subsuperficiales del Estrecho de Magallanes y Brazo Noroeste parecen estar semi-aisladas. La distribución de salinidad y temperatura sugiere que el flujo de aguas calientes y salinas del Pacífico se produce en Bahía Cook. Hacia el oeste y el norte, estas aguas se mezclarían progresivamente con aguas más frías y salobres provenientes de la Cordillera de Darwin. En este sector (Canal Brecknock-Canal Cockburn), la estratificación de la columna de agua fue más débil, y llegó a ser nula hacia el Estrecho de Magallanes (Seno Magdalena-Paso Ancho). La distribución de las propiedades hidrográficas y los perfiles batimétricos fueron consistentes y sugieren la siguiente sub-división de microcuencas a lo largo del transecto Magallanes-Beagle: 1.- Paso Ancho-Seno Magdalena, 2.- Canal Magdalena-Canal Brecknock, 3.- Canal Ballenero-Brazo Noroeste, 4.- Canal del Beagle.

Palabras clave: Hidrografía, batimetría, estrechos, microcuencas, fiordos, estuarios, aguas salobres, ventisqueros.

\footnotetext{
*Accepted January 4, 1999.
} 


\section{INTRODUCTION}

The coast line of southern South America west of the Andes mountains was broken down by quaternary glaciation to form a vast and long archipelago extending to Cape Horn. The complex web of channels, inlets and surrounding land masses form a system of basins whose hydrographic and ecological peculiarities are poorly known. Fjords as a type of estuary generally possess steep sides, rock bottoms (which may be thinly veneered with sediments), and underwater sills (Kennish, 1986). They are therefore, glacial troughs now partly occupied by the sea.

Located within the latitudinal range of the West Wind Drift and north of the Polar Front, this fjord system is influenced by Subantarctic adjacent waters and also by precipitation, continental runoff and melting ice. According to Pickard (1971; 1973), Chilean fjords are atypical when compared to British Columbian and Alaskan fjords because of less abundant freshwater runoff, the absence of sills in most inlets and because of a very complex temperature structure of the water column.

Pickard (1973) and Panella et al. (1991) pointed out that the westward influence of Atlantic waters in the Straits of Magellan extends through Paso Ancho, and the eastward influence of Pacific waters reaches Isla Carlos III, where a narrow constriction and a shallow sill exists (Antezana et al., 1992). Tidal cur- rent driven exchange between oceanic and inland waters takes place to a different extent at both western and eastern entrances (Panella et al., 1991). However, no description has been given of gradients or frontal conditions offshore, since results of those cruises did not cover adjacent oceanic waters.

The first objective of this work was to describe the characteristics of adjacent oceanic waters as a reference base to infer the degree of isolation of inland waters or their exchange between inland passages (such as the Canal Magdalena / Canal Cockburn / Canal Brecknock system and Canal Ballenero / Canal Beagle system), and with oceanic waters. (Spanish names from Chilean navigational charts are used in this study). These channels are connected with the Pacific Ocean and water exchange is expected to occur in peculiar ways which are not described yet. Most recent studies based on hydrographic (Panella et al., 1991), biological (Saggiomo et al., 1994; Carrada et al., 1994; Cabrini and Fonda Umani, 1991; Fonda Umani and Monti, 1991; Mazzocchi and Ianora, 1991) or geological (Brambati et al., 1991) features, identified basins within the Straits of Magellan and proposed environmental boundaries between them. Most of these boundaries coincided with a subdivision, based purely on bathymetric and topographic features (Antezana et al., 1992), which anticipated significant effects of both depth and side contours on water exchange between basins and with the open ocean.

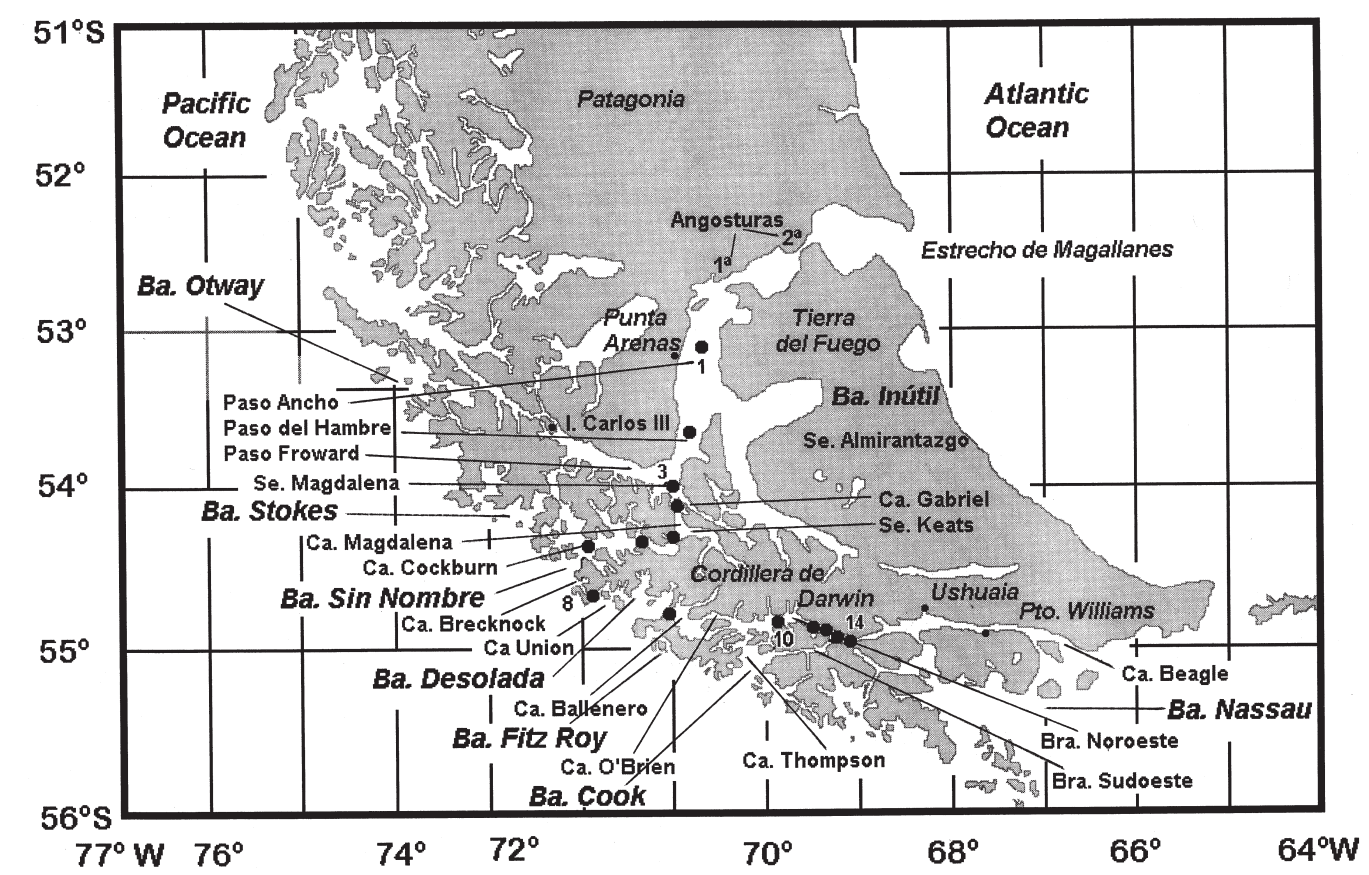

FIG. 1. - Distribution of hydrographic stations along the Straits of Magellan - Beagle Channel passage on board R.V. "Victor Hensen" in spring 1994. 
The second objective of this study was to examine bottom profiles and the distribution of water properties along these passages to identify basins within the system and to infer the extent of their exchange with open ocean waters and between basins. Particularly higher sampling resolution (stations were more closely located) was achieved in a most unique area of Brazo Noroeste, where numerous glaciers reach the sea surface.

\section{MATERIAL AND METHODS}

\section{The study area}

The study area (Fig.1) extended along a transect delimited by the normal navigation between Paso Ancho (off Punta Arenas) and Canal Beagle (off Puerto Williams) through the following Magellan and Fuegian passages in the same N-S order: Paso Ancho, Paso del Hambre, Seno Magdalena, Canal Magdalena, Canal Cockburn, Canal Brecknock, Canal Ballenero, Canal O'Brien, Brazo Noroeste and Canal Beagle. Bathymetry extended to connecting passages to the open ocean. The hydrographic description covered the area $1100 \mathrm{~km}$ offshore in the Subantarctic south eastern Pacific.

Paso Ancho is the widest part of the Straits of Magellan situated midway between the Atlantic and Pacific and extending toward the west into Bahía Inútil and toward the southwest to Canal Whiteside / Seno Almirantazgo. At the southernmost vertex of the V shaped Straits of Magellan, Paso del Hambre and Seno Magdalena narrow and extend southward into Canal Magdalena, and eastward to Canal Cockburn. At this point the channel system opens to the Pacific Ocean through Bahía Desolada. Eastward into Canal Brecknock, Canal Unión, Canal Ballenero and Canal O'Brien, the coast line is more broken to the north by small and narrow inlets and to the south by connections to the Pacific Ocean at Bahía Fitzroy (at the junction of Canal Unión and Canal Ballenero) and Bahía Cook (at the junction of Canal Thompson and Brazo Sudoeste). Eastward into Brazo Noroeste and Canal Beagle the passage is narrower and is broken and bordered by glaciers on the north side and a narrow passage on the west side of Isla Navarino. On the east side of this Island the passage opens widely toward the Cape Horn.

The main sources of continental fresh waters within this area seem to be associated with Cordillera de Darwin, the southern extension of the
Andes mountains, located along the southwestern sector of Tierra del Fuego. Melting ice and precipitation waters likely entered the system through 1.Seno Almirantazgo into Bahía Inútil and Paso Ancho, 2.- Canal Gabriel and Seno Keats into Canal Magdalena and Seno Magdalena, and 3.- along inlets and glaciers on the north side of Brazo Noroeste and Canal Beagle.

\section{Data collection}

This study is mainly based on data collected during the Magellan campaign of R.V. "Victor Hensen" leg 1 and 2 carried out in November 1994 (Arntz and Gorny, 1994; Antezana et al., 1996) during the dry season of the year. Additional data from the Piquero Expedition (Fig. 2) on board R. V. "Thomas Washington" during January-February 1969 (Anon, MS) and some published data from Atlantic waters adjacent to Tierra del Fuego (Reid, 1994; Sánchez et al., 1993) are also included.

On transit between Punta Arenas and Puerto Williams (2-6 November), 14 stations were occupied at 5-10 miles intervals (Fig. 1) with greater gaps in Paso Ancho and Canal Ballenero and

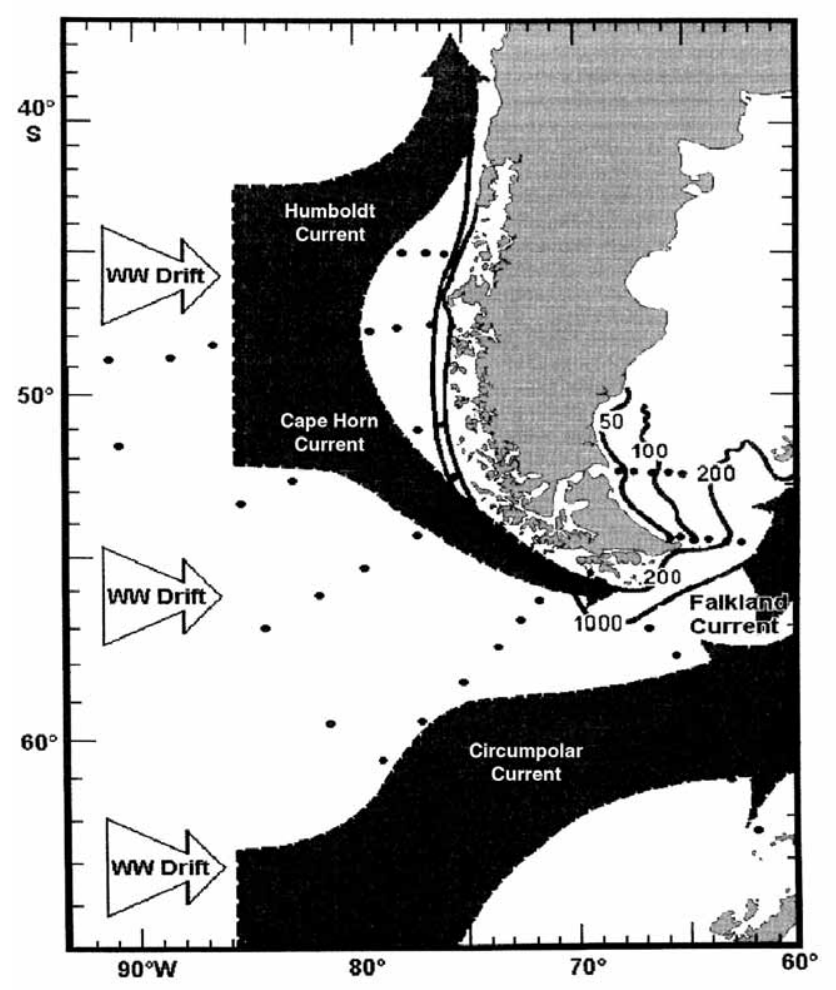

FIG. 2. - Schematic distribution of main currents and isobaths near the tip of South America and distribution of hydrographic stations during the Piquero III expedition in summer 1969. 
much smaller intervals in the glacier sectors of Brazo Noroeste, particularly in front of glaciers Garibaldi and Italia. At every station echo-sounding measurements of bottom depth determined the maximum suitable depth for the STD cast which was $200-300 \mathrm{~m}$ in most cases. Tidal currents, wind stress and uneven bottom topography prevented sampling closer than 20-30 m from the bottom. A Sensor Data SD-202 STD was used at most stations except for the stations in Paso Ancho where a Sea Bird SBE19 was used. Previous calibrations of these instruments gave reliable accuracy, relative to the wide range of salinities found. The data were recorded in analog format during STD
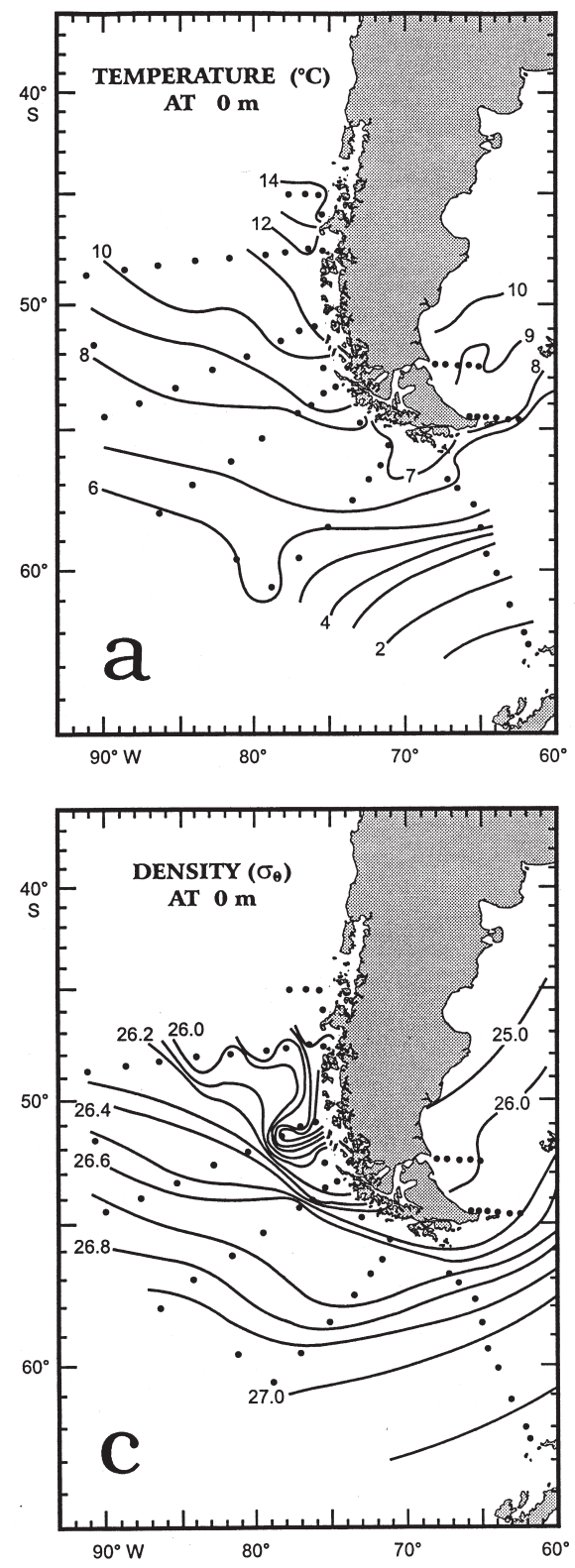

FIG. 3. - Distribution of isolines during Piquero III expedition . a.- Temperature at $0 \mathrm{~m}$, b.- Salinity at $0 \mathrm{~m}$, c.- Density at $0 \mathrm{~m}$; d.- Salinity at $50 \mathrm{~m}$.
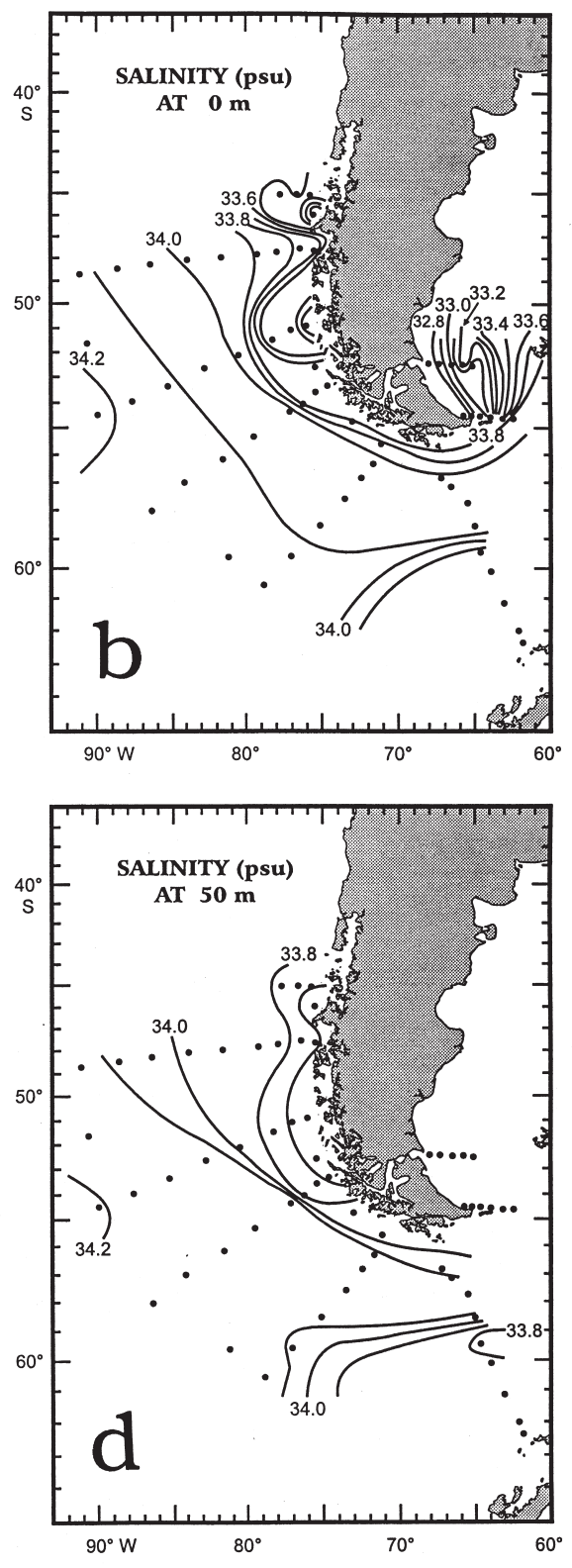

descent. Salinity sections are given in practical salinity units (psu), temperature in ${ }^{\circ} \mathrm{C}$ and potential density in $\mathrm{kg} / \mathrm{m}^{3}$.

Two liter Niskin bottle casts at fixed depths of 0 , $2,5,10,15,50 \mathrm{~m}$ and in some stations 75 and 100 $\mathrm{m}$ followed. Water samples were drawn for phytoplankton identification and photo pigments and nutrient measurements. A bongo net cast to $50 \mathrm{~m}$ depth followed and ended the station. Most stations took place at night hours.

Bathymetry profiles were obtained from navigational charts of the Chilean Hydrographic Institute, by plotting the best approximate depth value at one mile intervals along the axis of the passage.

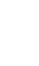




\section{RESULTS}

\section{Subantarctic waters surrounding South America}

The main source of surface water approaching the southern cone of South America (Fig.2) comes from the West Wind Drift which deflects south to form the Cape Horn Current, as seen from potential density isolines (Fig.3c). Beyond Cape Horn, Subantarctic waters as part of the circumpolar current system continue eastward and northward, beyond the continental shelf to form the Falkland (Mal-vinas) Current. Toward the coast, Subantarctic waters mix with channel waters from rivers, glaciers, precipitation and continental runoff to produce a belt of brackish waters surrounding the tip of South America (Fig. $3 \mathrm{~b})$. This layer did not extend much deeper than 50 $\mathrm{m}$ on the Pacific side (Fig. 3d). The surface salinity minimum on the Atlantic was associated with the outflow of Straits of Magellan waters; it is very wide, extending across the entire Argentinian shelf. On the Pacific side, the salinity minimum was very narrow, as Subantarctic oceanic waters are separated from the fjord system by a very narrow continental shelf. Furthermore, salinities were higher than on the Atlantic shelf. This difference could be accounted for by a greater contribution of deeper higher salinity waters near the Pacific coast. The shallow salinity minimum layer associated with fjords was wider at the middle and northern sectors of the fjord region and narrowed southward to Cape Horn where it was restricted to a very thin layer. Therefore Subantarctic waters reaching the Magellan channels have lesser salinity than those approaching the more southern Fuegian channels.

Sea surface temperature distribution (Fig. 3a) showed similar tendencies as salinity (Figs. 3b, 3d) and potential density distributions (Fig. 3c). Associated with the formation of the Cape Horn Current, isotherms form a wedge of warm water with decreasing temperatures southward, with higher values off the Magellan channels and lower values off the Fuegian channels. Beyond Cape Horn, low temperature waters merging with the Antarctic Circumpolar Current flow north and were mostly excluded from the Argentinean shelf sector.

In conclusion, Subantarctic surface waters within the latitudinal range of the West Wind Drift had different characteristics in the Pacific and the Atlantic sectors adjacent to the coast of South America. On the extensive Patagonian shelf, surface temperature ranged between 8.4 and $9.4{ }^{\circ} \mathrm{C}$ and salinity between 32.7 and 33.7. Temperature of surface waters within $220 \mathrm{~km}$ off the Chilean Fuegian channels ranged between 6.9 and $7.9{ }^{\circ} \mathrm{C}$ and salinity between 33.8 and 34.1, while off the Magellan channels temperature ranged between 7.5 and $9.5^{\circ} \mathrm{C}$ and salinity between 33.6 and 33.8. Beyond the Argentinean shelf both temperatures and salinities of Pacific and Atlantic waters were more similar.

\section{Depth profiles along the inland passages to the open ocean}

The main connections from these inland passages to open Pacific waters as indicated in navigational charts (Fig. 1) are: 1.- SW of Canal Cockburn (Bahía Sin Nombre), 2.- Canal Union (the SE extension of Canal Brecknock), 3.- the confluence of Canal Brecknock and Canal Ballenero (S of Bahía Desolada), 4.- half way along Canal Ballenero (through Bahía Fitz-Roy), 5.- Canal Thompson, (the southward extension of the confluence of Canal O'Brien / Brazo Noroeste), and Brazo Sudoeste (through Bahía Cook) and 6.- the easternmost entrance of Canal Beagle.

Without attempting a detailed description of the bottom profile, some features likely to affect water circulation are pointed out (Fig. 4). Paso Ancho basin in the Straits of Magellan extends southward beyond Paso del Hambre to form Seno Magdalena, a shallower rise about halfway between the Pacific and the Atlantic. Southward, Canal Magdalena follows a straight $\mathrm{N}-\mathrm{S}$ direction and merges into Canal Cockburn which runs westward to connect to the Pacific.This section (Fig. 4a) is rather deep with a mound of $200 \mathrm{~m}$ at the entrance of Canal Magdalena and a net downward slope toward the open ocean which is separated by a $30 \mathrm{~m}$ sill. Canal Cockburn opens in a straight southerly direction but this entrance is fringed by several small islands which divide the mouth of Canal Cockburn into several shallow passages. The confluence with Canal Brecknock is also connected to the ocean by the same sill of $30 \mathrm{~m}$ extending eastward.

The section along Canal Brecknock, Canal Ballenero, Canal O'Brien and Brazo Noroeste (Fig.4b) is relatively shallow and could be divided into two sectors by a rise of $30-50 \mathrm{~m}$ at the western end of Canal O'Brien: 1.- Canal Brecknock / Canal Ballenero and 2.- Canal O'Brien / Brazo Noroeste.The former sector with a zig-zag shape on a net WE direction, is connected to the open Pacific waters in several locations on the southern side and to several 


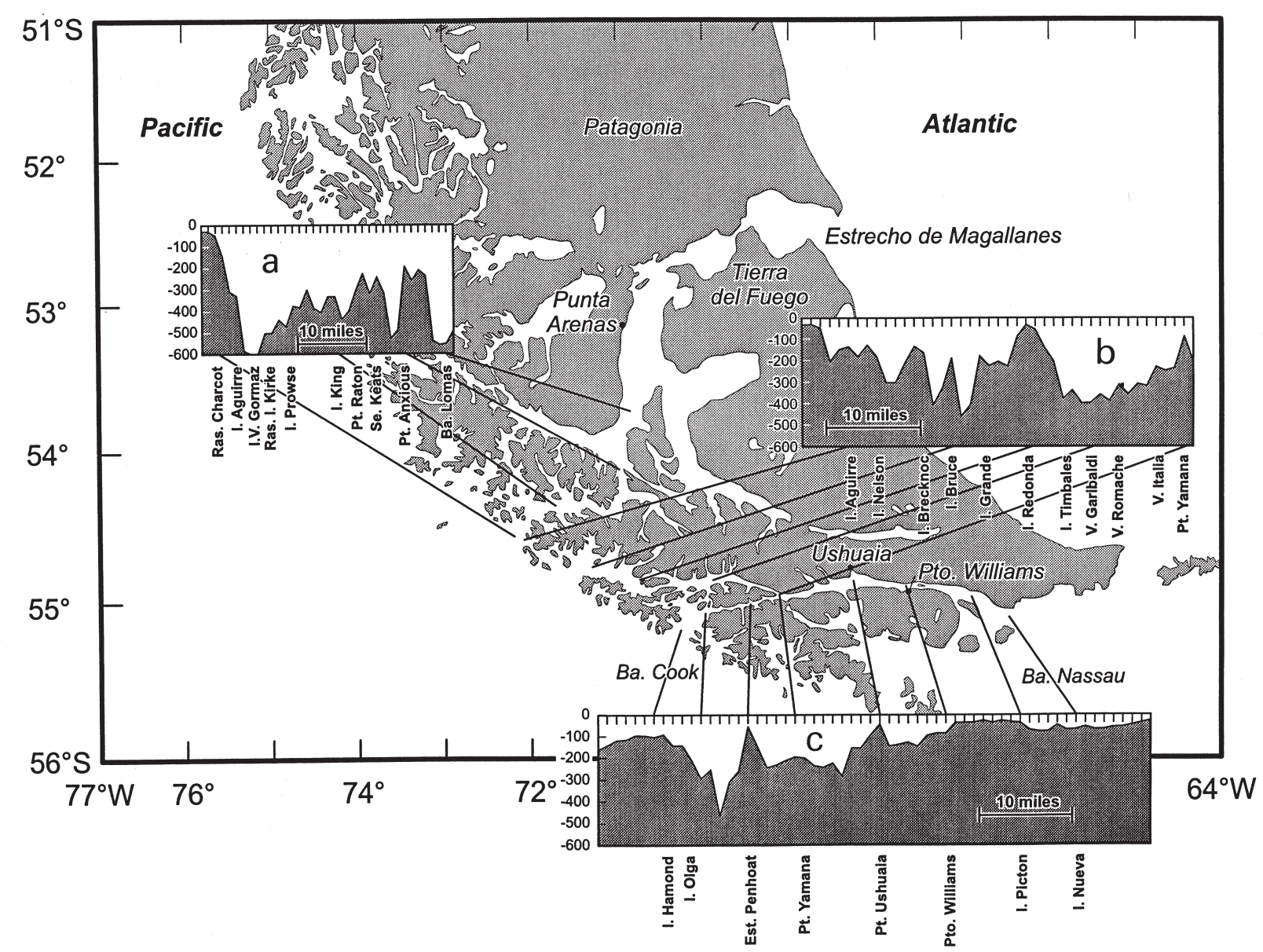

FIG. 4. - Bottom profiles along three main Magellan and Fuegian passages. Depth in meters. a.- Pacific Ocean (Bahía Sin Nombre) / Canal Cockburn / Canal Magdalena / Seno Magdalena / Paso del Hambre / Paso Ancho; b.- Pacific Ocean (Bahía Sin Nombre) / Canal Brecknock / Canal Ballenero / Canal O’Brien / Brazo Noroeste; c.- Pacific Ocean (Bahía Cook) / Brazo Sudoeste / Canal Beagle / Pacific Ocean (Bahía Nassau).

inlets on the northern side. South of Bahía Desola$\mathrm{da}$, another area of fresh water influx on the S side of Cordillera de Darwin, Canal Brecknock joins Canal Ballenero. This wide opening is in fact a labyrinth formed by small islands with two main passages connecting inland waters from open Pacific waters over a sill of $40 \mathrm{~m}$. The former passage merges into the western entrance of Canal O'Brien over a shallow sill (at Isla Redonda) and into Canal Ballenero which is wide and deep. At their confluence next to Isla Timbales, is Canal Thompson, a 20 $\mathrm{km}$ long and 200-650 m deep passage which connects the Canal Ballenero / O'Brien / Brazo Noroeste system to the Pacific through Bahía Cook. This is the deepest connection to the Pacific of the study area. Brazo Noroeste is a deep basin reaching $350-400 \mathrm{~m}$ and ending on the east in a narrow and shallow $(80 \mathrm{~m})$ constriction (at Isla del Diablo) which abruptly separates it from Canal Beagle in the Punta Yámana sector.
The section along Brazo Sudoeste / Canal Beagle (Fig.4c) could be divided into three sectors by a peak of $30 \mathrm{~m}$ half way along Brazo Sudoeste and by another sill of $45 \mathrm{~m}$ at Punta Ushuaia. The depth profile of the deep western sector extends into Bahía Cook which is also connected to Canal Thompson. Bahía Cook is separated from the open Pacific by a $40 \mathrm{~m}$ sill at Isla Hammond which is somewhat deeper than other open ocean waterways of the study region. The eastern sector of Brazo Sudoeste has a shallow bottom which merges into Canal Beagle as a continuum. Eastward, Canal Beagle is progressively shallower particularly beyond Puerto Williams $(40-60 \mathrm{~m})$ extending to the eastern entrance for $75 \mathrm{~km}$ to open into the wide and shallow continental shelf on Bahía Nassau next to Cape Horn.

In summary, since the connections of Pacific waters to the inland passages are limited by sills or shallow plains of $30-40 \mathrm{~m}$, continuity between pas- 
sages could be established in a single profile from the eastern entrance of Canal Beagle to Paso Ancho in the Straits of Magellan. Considering just depth profiles and other topographic accidents such as lateral contractions along the passages, the following subdivisions of microbasins are proposed:

1.- Seno Magdalena extending to Paso Froward and Paso Ancho, 2.- Canal Magdalena / Canal Cockburn, 3.- Canal Brecknock to Canal Ballenero, 4.Brazo Noroeste, 5.- Canal Beagle / Brazo Sudoeste.

\section{Waters within main passages}

Vertical distribution of temperature, salinity and density are depicted in the two main sections: Seno Magdalena / Canal Magdalena / Canal Cockburn / Canal Brecknock Passage (Fig. 5) and Canal Brecknock / Canal Ballenero / Canal Noroeste / Canal Beagle Passage (Fig. 6). Data from Canal Brecknock were plotted in both transects as they are at the confluence of both passages. Data from coastal Pacific waters from the Piquero expedition (in late spring) were included as coastal open ocean reference stations.

\section{Paso Ancho / Seno Magdalena / Canal Magdalena / Canal Cockburn / Canal Brecknock Passage.}

Distribution of isopycnals (Fig. 5a) showed an abrupt upward deflection toward Canal Brecknock and an abrupt downfall at the entrance of Canal Magdalena (Punta Anxious). The most homogeneously distributed densities of the entire study area occurred at Seno Magdalena (Isla Peak) where the $24.4 \mathrm{~kg} / \mathrm{m}^{3}$ layer extended to $200 \mathrm{~m}$. In and around Paso Ancho there was a slight water stratification associated with a lens of $24.4-24.2 \mathrm{~kg} / \mathrm{m}^{3}$ in the upper $50 \mathrm{~m}$. Vertical distribution of densities near the Pacific entrance at the confluence of Canal Cockburn and Canal Brecknock presented a strong gradient.

The distribution of isohalines (Fig. 5b) mirrored the density distribution with a similar abrupt front at the Pacific entrance and a transition between homogeneous conditions of Seno Magdalena to stratified conditions of the Canal Cockburn / Canal Brecknock passage. The high salinity deep layer found in Canal Brecknock and Canal Cockburn gradually disappeared to a completely mixed water column of 31.1-31.3 salinity.

Temperature distribution (Fig. 5c) showed an abrupt difference between warm Pacific waters and
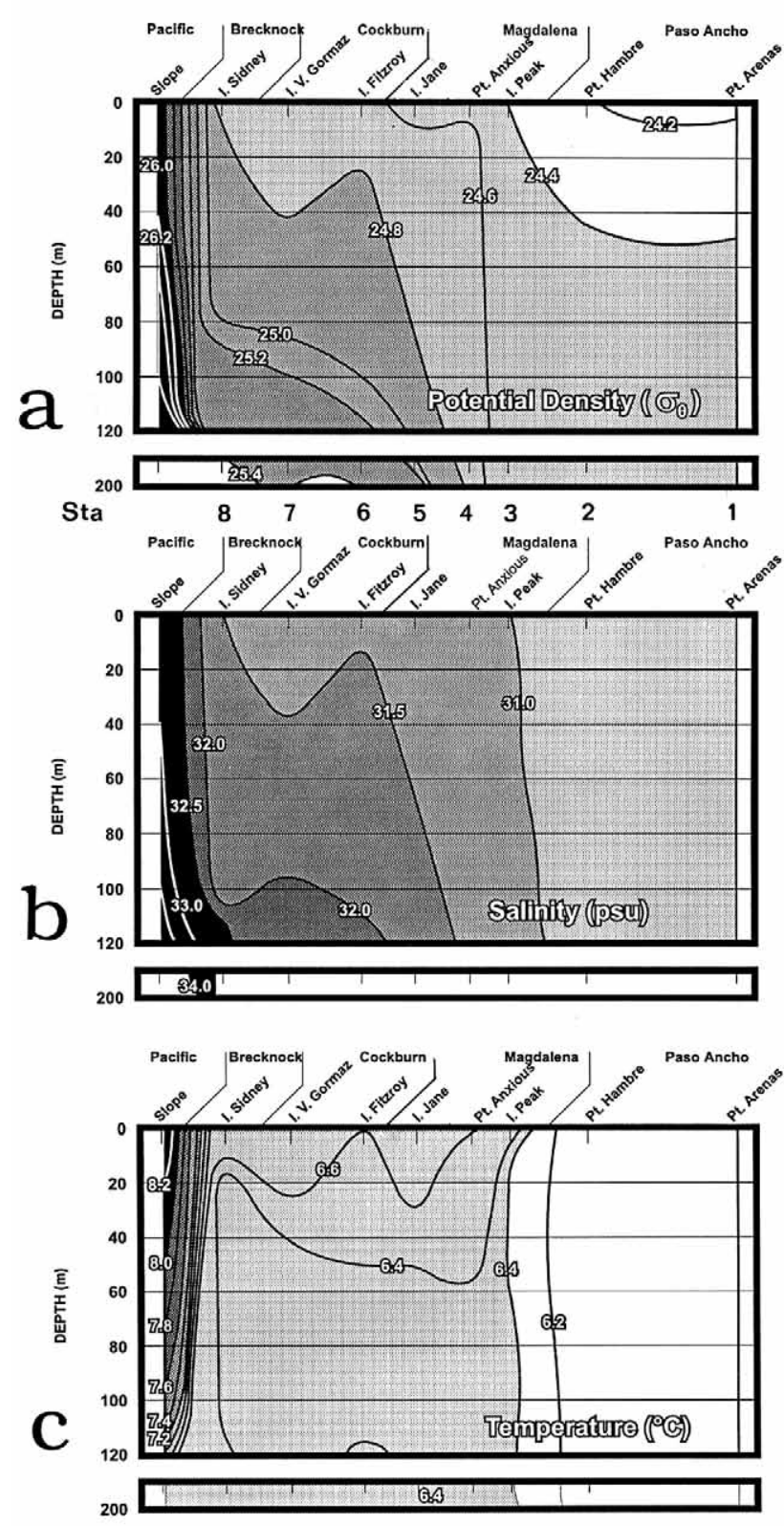

FIG. 5. - Vertical distribution of water properties along the transect Paso Ancho / Canal Magdalena / Seno Magdalena / Canal Cockburn / Canal Brecknock / Pacific Ocean in spring 1994. a.- Density; b.Salinity; c.- Temperature.

inland waters. The Paso Ancho / Paso del Hambre / Seno Magdalena sector showed the coldest waters and complete thermal homogeneity to $200 \mathrm{~m}$ (which extended to $300 \mathrm{~m}$ according to the deepest data collected at these stations). The Canal Magadalena / Canal Cockburn / Canal Brecknock sector showed instead a surface lens of warmer water. This was the only sector of the entire study area where a shallow warm water layer was found. A thermal front, shown by the upward deflection of the $6.4{ }^{\circ} \mathrm{C}$ isotherm to the surface was observed in Seno Mag- 
dalena, $c a .10 \mathrm{~km}$ north of the entrance of Canal Magdalena (Punta Anxious).

\section{Canal Brecknock / Canal Ballenero / Canal O'Brien / Brazo Noroeste / Canal Beagle Passage}

Distribution of densities (Fig. 6a) indicated important gradients toward the Pacific and at the confluence of Canal Noroeste and Canal Beagle near Punta Yámana. A shallow lens of low potential density (less than $24.5 \mathrm{~kg} / \mathrm{m}^{3}$ ) occurred along the glacier sector of Brazo Noroeste. Nearby a deep wedge of high density impinged upward to about 40 $\mathrm{m}$ in the eastern sector, but did not extend beyond the confluence with Canal Beagle (and Brazo Sudoeste) where the bathymetry profile indicated a sill of $80 \mathrm{~m}$. In the westernmost sector (at Isla Sidney), waters with similar densities were homogeneously distributed in the water column to $90 \mathrm{~m}$.

Vertical distribution of isohalines (Fig. 6b) along the same section mirrored the distribution of isopycnals. A lens of lowest salinities extended throughout the glacier sector of Brazo Noroeste to gradually disappear through Canal Ballenero and Canal Brecknock. A subsurface layer of higher salinity waters occurred here and was particularly obvious toward the deepest and easternmost sector. This core diffused westward. It was barely present toward the easternmost part of Brazo Noroeste (Ventisquero Italia) and did not reach Punta Yámana on the Canal Beagle.

Vertical distribution of isotherms (Fig. 6c) along this section showed a subsurface warmer wedge rising eastward with a core of $>8^{\circ} \mathrm{C}$ in the glacier sector of Brazo Noroeste. Overlying this warm layer there was a cold upper layer (10-40 m of water less than $6^{\circ} \mathrm{C}$ ), which was thinner on the glacier sectors and thickened westward. Both cold upper and warm deep layers were separated by strong thermoclines which deepened in the $\mathrm{E}-\mathrm{W}$ direction.

In summary, vertical sections of density, temperature and salinity along the Straits of Magellan to Canal Beagle suggest the subdivision of the following microbasins:

1.- Seno Magdalena / Paso del Hambre / Paso Ancho, 2.- Canal Magdalena / Canal Cockburn / Canal Brecknock, 3.- Canal Ballenero / Canal O’Brien / Brazo Noroeste, 4.- Canal Beagle.

No clear separation was noticed between Canal Brecknock, Canal Ballenero, Canal O'Brien and Canal Noroeste; waters were rather homogeneous within this sector but clearly distinct from Canal Beagle and open shelf Pacific waters.
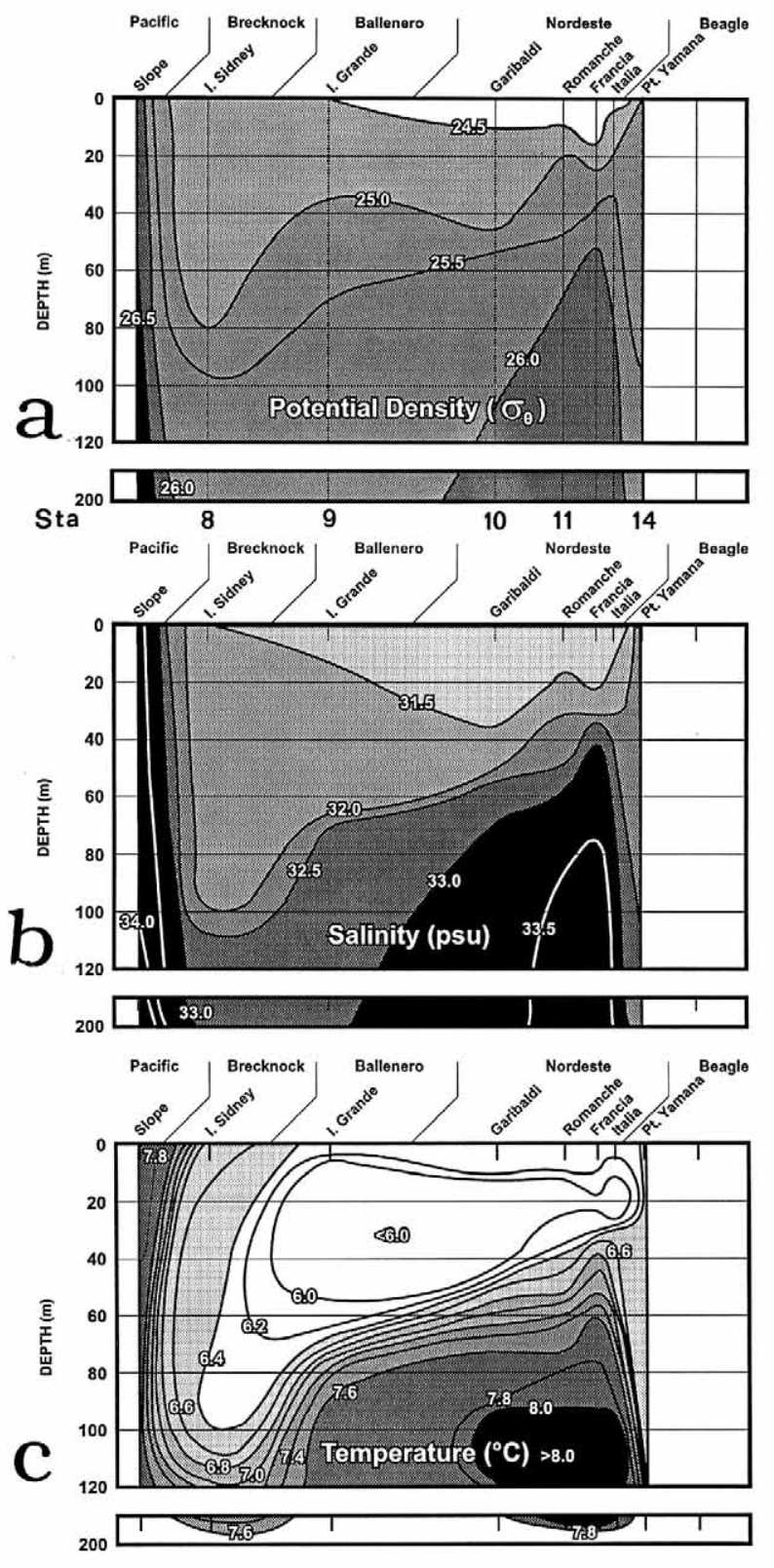

FIG. 6. - Vertical distribution of water properties along the transect Canal Beagle / Brazo Noroeste / Canal Ballenero / Canal Brecknock / Pacific Ocean in spring 1994. a.- Density; b.- Salinity; c.- Temperature.

A continuous gradient of increasing salinity from Paso Ancho toward the eastern entrance of Canal Beagle is shown, when data of the entire study area are depicted in a single profile along the inland passages while ignoring connections to oceanic Pacific waters. Nevertheless, some other oceanographic features suggest the subdivision of micro basins. For example, Paso Ancho / Seno Magdalena had vertically mixed low salinity and cold water. Brazo Noroeste / Canal Ballenero had temperature inversions and two thermal and haline layers, with the 

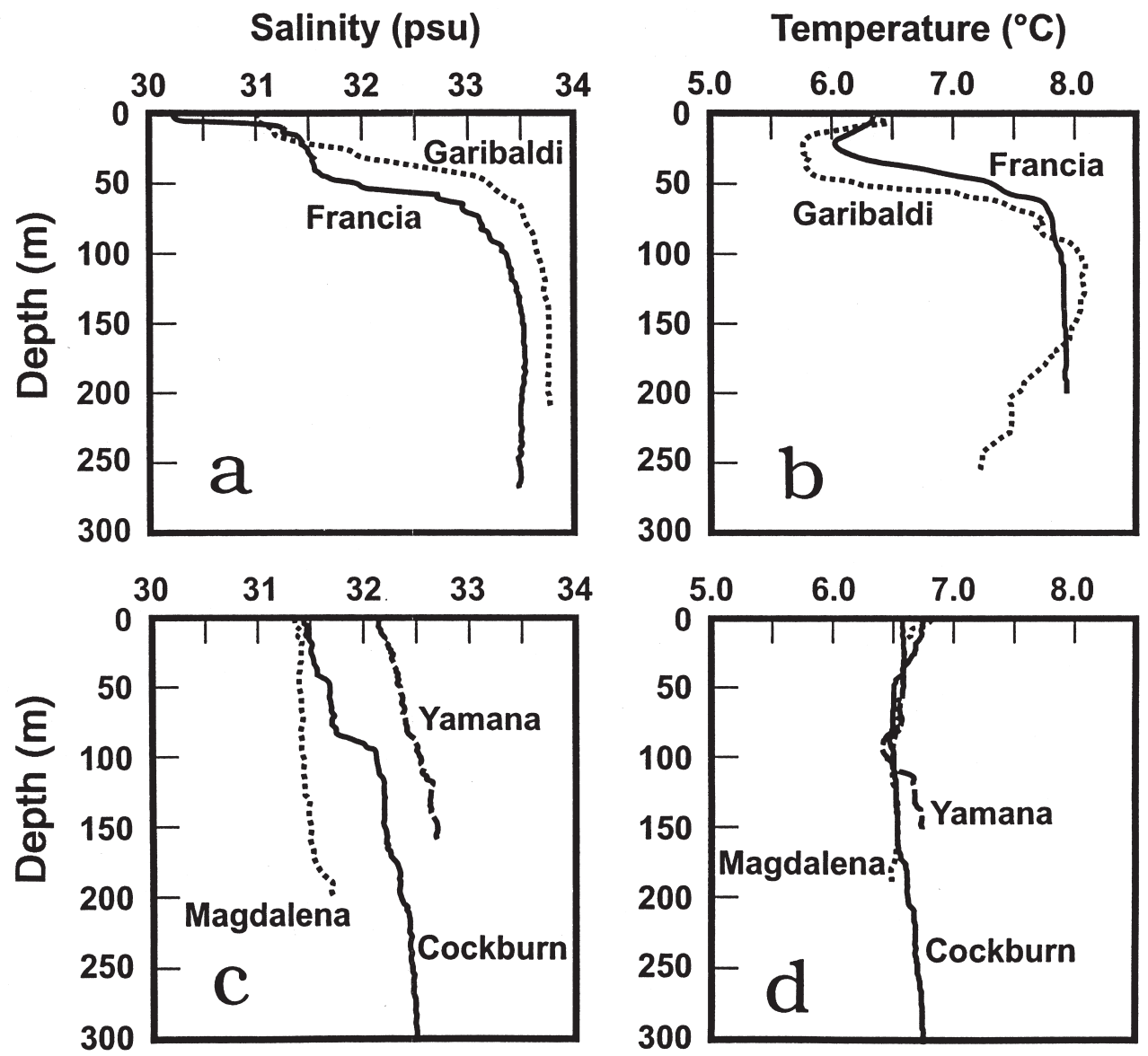

FIG. 7. - Vertical distribution of temperature and salinity at selected sites of the Straits of Magellan - Beagle Channel passage where the water column was strongly stratified next to the glaciers Ventisquero Francia and Ventisquero Garibaldi (a-b) and more or less homogeneous in Canal Cockburn, Seno Magdalena and Canal Beagle at Punta Yámana (c-d).

warmest and saltiest waters at depth. Canal Magdalena / Canal Cockburn showed intermediate water properties with moderate salinity, temperature and vertical stratification. Canal Brecknock had clearly transitional water conditions.

Finally surface temperature distribution in the upper $40 \mathrm{~m}$ throughout the entire region was rather constant around $6.5{ }^{\circ} \mathrm{C}$, which was about $1-3{ }^{\circ} \mathrm{C}$ lower than the Subantarctic surrounding shelf waters. The glacier sector of Brazo Noroeste was the only sector where a deep layer of warm waters similar to the surrounding shelf waters was detected.

\section{Vertical stratification}

Selected profiles of vertical distribution of temperature and salinity are depicted in order to stress differences between and to some extent within microbasins. Maximum stratification occurred in the glacier sector e.g. off glaciers Francia and Garibaldi (Fig. 7a-b). Overlying a high salinity layer which extended to the bottom, there was a strong halocline above $80 \mathrm{~m}$, which reached the surface at glacier Garibaldi and broke into two shallow layers at glacier Francia. Temperature showed inversions associated with several overlying layers: an upper warm (and brackish) layer less than $5 \mathrm{~m}$ thick over a cold and also brackish subsurface layer of 30-50 m, and both over the warm deep layer of saline waters which extended to $250 \mathrm{~m}$ depth.

A more moderate stratification of salinity was observed in Canal Cockburn (Fig. 7c-d) where a weaker halocline was found at $c a .80 \mathrm{~m}$; temperature instead, was not stratified in this sector with the exception of a slight gradient in the upper 30 $\mathrm{m}$. Homogeneously distributed waters appeared in Seno Magdalena and in Punta Yámana both with similar temperatures $\left(c a .6 .6{ }^{\circ} \mathrm{C}\right)$ but higher salinities in Punta Yámana than in Seno Magdalena. Moderate stratification or transition conditions were found along Canal Brecknock and Canal Ballenero. 


\section{DISCUSSION}

Distribution of water properties was consistent with general ocean current circulation indicating a southward deflection of the West Wind Drift to form the Cape Horn Current extending along the Chilean fjord region to Cape Horn. Although the entire latitudinal range was affected by the outflow of freshwater from the inland passages, differences were identified in temperature, salinity and density distribution between the Pacific and Atlantic coastal waters, as well as between the more northerly Straits of Magellan and the southern Fuegian fjords on the Pacific. One must bear in mind, however that this study includes data from different cruises and does not consider seasonal variability. The lack of sampling through the connecting passages and in the immediate open shelf waters in the Pacific is also a limitation.

Even so, limited water exchange between inland passages and the open ocean is suggested by the presence of warm and salty waters in only some passages and the direction of temperature, salinity and density gradients. Despite major connections to the Pacific at the mouths of Canal Cockburn, Canal Brecknock, Canal Ballenero and Canal Beagle, the presence of shallow sills here is likely to constrain water exchange to the upper $30-40 \mathrm{~m}$. In particular, the shallow depth of the eastern end of Canal Beagle apparently restricts the inflow of subsurface ocean water. Since water exchange with the Pacific is limited and is apparently taking place through narrow and shallow openings, most of the water filling the Magellan and Fuegian basins must be semi isolated or trapped in this season.

Despite sampling depth restrictions (mainly in the upper $200 \mathrm{~m}$ ), profiles of water properties suggested that water exchange is less constrained between inland passages than across the Pacific sills. Furthermore, other bathymetric features and lateral contractions within the inland passages which would affect water circulation, also explain the hydrographic characteristics and subdivisions of microbasins within this system. Exceptionally, the sill on the axis of Canal O'Brien which separates Brazo Noroeste and Canal Ballenero had no apparent effect on water circulation. The use of bathymetric features to define microbasins in the Straits of Magellan (Antezana et al., 1992) was consistent with the distribution of water properties (Panella et al., 1991), copepods (Mazocchi and Ianora, 1991), microzooplankton (Fonda Umani and Monti, 1991) and meso- and macrozooplankton (Guglielmo et al., 1991) in this passage.

One of the most obvious effects of bathymetry on hydrographic discontinuities took place at the confluence of Brazo Noroeste and Canal Beagle where both a depth and lateral contraction occur west of Punta Yámana. Westward into Brazo Noroeste, the water column was well stratified while eastward it was homogeneous. Water characteristics of Canal Beagle at Punta Yámana (salinity 32.2 and temperature $6.6^{\circ} \mathrm{C}$ through the water column) indicated a slight inflow of Pacific water, likely mixed with cold and fresh water from runoff and from the glaciers of Brazo Noroeste. Eastward the influence of Pacific waters was probably greater. Some preliminary studies in early autumn suggest a westward inflow of even warmer and slightly saltier oceanic water into Canal Beagle (Celio, 1991). However the warm deep layer $\left(>8.5^{\circ} \mathrm{C}\right)$ found in Brazo Noroeste / Canal Ballenero did not appear east of Puerto Williams where depth is less than $50 \mathrm{~m}$. Therefore, current data did not support the intrusion of Pacific waters through Canal Beagle into Brazo Noroeste in spring.

The effect of melting water from several glaciers reaching the surface on the northern side of Brazo Noroeste (as evidenced by a vertically well stratified layer of very cold and brackish water), was a significant feature in the hydrography of these inland passages. Vertical inversion was probably related to winter cooling and successive spring warming and also to local cooling in the proximity of glaciers (Pickard, 1971, 1973). This cold and brackish layer did not mix much with the overlying warm and salty waters because of a strong pycnocline. Rather, this cold and brackish layer slid down along Canal Ballenero to reach a depth of $100 \mathrm{~m}$ at the confluence with Canal Brecknock. This glacier water mixed gradually with even less saline and warmer waters near the Canal Brecknock / Canal Cockburn / Canal Magdalena system.

The influence of melting waters from Cordillera de Darwin on its northern and western sides was not evident in Canal Magdalena, (where Seno Keats opens), but rather in the Seno Magdalena / Paso Ancho sector where both Canal Gabriel and Seno Almirantazgo open into this area. Therefore, the area of confluence of the Straits of Magellan waters and the southern Magellan fjords system took place in Seno Magdalena where frontal conditions were found (Punta Anxious / Isla Peak), during this spring. The presence of a significant inflow of 
brackish water was also suggested by Celio (1991) and Panella et al. (1991) at Canal Magdalena and Seno Magdalena during autumn and spring, respectively .

The underlying waters of Brazo Noroeste were the warmest and saltiest found in the study area ( $8.05{ }^{\circ} \mathrm{C}$ and $33.5 \mathrm{psu}$ at the core). This body of water showed extreme values at the confluence with Canal Beagle (to the west of Punta Yámana) which became an effective barrier for this apparently trapped water. Westward, this densest water (25.5.$26 \mathrm{~kg} / \mathrm{m}^{3}$ ) clearly of Pacific origin spread through Canal Ballenero and eventually may reach the Canal Brecknock / Canal Cockburn / Canal Magdalena basin. These observations are consistent with a northward inflow of Pacific waters suggested by Celio (1991). However the location of this inflow of Pacific waters is not consistent with shallow sills of connecting shelf passages. The Pacific water might have entered through Bahía Cook which is deeper and closer to the open Pacific than through other connecting passages, as a shallow dense water layer sliding along the bottom of the basin. Alternatively, this water could have entered through the eastern mouth of Canal Beagle in the summer, to cool down and descend in winter, to be finally trapped in the Canal Ballenero / Brazo Noroeste system.

Mixing of deep saline and overlying brackish water took place along Canal Brecknock / Canal Cockburn (deep salinity layer over 32 psu) and Canal Magdalena to reach homogeneous conditions in Seno Magdalena / Paso Ancho. Various factors could work together to produce such homogenous conditions. The combined effect of tidal currents, wind stress, internal friction and bottom friction to overcome the stratifying effect of freshwater discharge was suggested by Panella et al. (1991) in the western entrance of the Straits of Magellan. Indeed, tide and wind induced mixing may be equally effective in wide basins such as Paso Ancho / Seno Magdalena and much less effective in narrow deep basins such as Brazo Noroeste and Canal Ballenero where the stratifying effect of fresh water discharge may be more pronounced.

In conclusion, patterns were identified in water properties which were associated with major bathymetric features, including the presence of shallow connecting sills to the Pacific ocean, which supported a subdivision of basins within the inland passage system, despite the assumed complexity of the study area, the short term of this study, and seasonal variability. Profiles of water properties suggested that water exchange is less constrained between inland passages than across the Pacific sills suggesting that this fjord system is rather semiclosed. These results may be an important framework for understanding distribution, linkages and biological adaptations of organisms in the context of the multidisciplinary effort involved in the R.V. "Victor Hensen" campaign.

\section{ACKNOWLEDGEMENTS}

This research was funded by Alfred Wegener Institute, the University of Concepción during the R.V. "Victor Hensen" cruise and JGOFS-Chile, SIDA-CONICYT project during succeeding stages. I am deeply indebted to co-workers Sergio Jara and Yoanna Eissler who shared ideas, work and cheerfulness on deck and in the laboratory. During the last stage of data processing and writing, I spent a sabbatical leave of absence at the Marine Life Research Group of Scripps Institution of Oceanography and the Coastal Fisheries Resources Division of SouthWest Fisheries Science Center, NOAA in La Jolla, where a wide source of support was provided. Special thanks go to Michael Mullin and John Hunter. My acknowledgements are also extended to Roy Allen for his dedication and skilful illustrations. Idiomatic improvement and editing of the manuscript was graciously done by long time friends and colleagues Roger Leong and Kristen Ray to whom I am always grateful, as well as to Ingo Wehrtmann and two anonymous referees.

\section{REFERENCES}

Anon, MS. - Physical and Chemical Data. Piquero Expedition. 16 December 1968-16 April 1969. SIO Reference 74-27, pp. 1-59. Univ. California, San Diego.

Antezana,T., L.Guglielmo and E. Ghirardelli. - 1992. Microbasins within the Strait of Magellan affecting zooplankton distribution. In: V. Gallardo, O. Ferreti and H.I. Moyano (eds.): Oceanografía en Antartica ENEA Proyecto Antarctica - Italia, pp. 443-458. Ediciones Documentas, Santiago.

Antezana, T., M. Hamamé, Y. Eissler and S. Jara. - 1996. Hydrography of Chilean fjords: Strait of Magellan to Beagle Channel (leg 1 and 2). Ber. Polarforsch., 190: 16-18.

Arntz, W. and M. Gorny. - 1994. Cruise report of the Joint ChileanGerman-Italian Magellan “Victor Hensen” Campaign in 1994. Ber. Polarforsch., 190: 1-113.

Brambati, A., G. Fontolan and U. Simeoni. - 1991. Recent sediments and sedimentological processes in the Strait of Magellan. Mem. Biol. Mar. Ocean., 19: 217-259.

Cabrini, M. and S. Fonda Umani. - 1991. Phytoplankton population in the Straits of Magellan. Mem. Biol. Mar. Ocean., 19: 151151.

Carrada, G.C., M. Fabiano, P. Povero and V. Saggiomo. - 1994. Surface distribution of size-fractionated chlorophyll a and par- 
ticulate organic matter in the Strait of Magellan. Polar Biol., 14 (7): 447-454.

Catalano, G. and A. Goffart. - 1991. Dissolved oxygen and nutrients in the Straits of Magellan. In: F. M. Faranda and L. Guglielmo (eds.), Straits of Magellan Oceanographic Cruise, February-March 1991. Data Report. Part I: Physical, Chemical and Biological Oceanography, pp. 53-65. Ital. Natl. Sci. Comm. Antarct., Genova.

Celio, M. - 1991. Preliminary report on thermohaline features of Canales Beagle, Ballenero, Brecknock, Cockburn and Magdalena (Southern Hemisphere), Autumn 1991. Mem. Biol. Mar. Ocean., 19: 281-286.

Fonda Umani, S. and M. Monti. - 1991. Microzooplankton populations in the Strait of Magellan. Boll. Ocean. Teor. Appl., 9 (23) :151-162.

Guglielmo, L., T. Antezana, G. Constanzo and G. Zagami. - 1991. Zooplankton communities in the Straits of Magellan. Mem. Biol. Mar. Ocean., 19: 157-161.

Kennish, M.J. - 1986. Ecology of Estuaries. Volume I. Physical and Chemical Aspects. CRC Press Inc., Florida.

Mazzocchi, M.G. and A. Ianora. - 1991. A faunistic study of the copepod assemblages in the Strait of Magellan. Boll. Ocean.
Teor. Appl., 9 (2-3): 163-177.

Panella, S., A. Michelato, R. Perdicaro, G. Magazzù, F. Decembrini and P. Scarazzato. - 1991. A preliminary contribution to understanding the hydrological characteristics of the Strait of Magellan: Austral Spring 1989. Boll. Ocean. Teor. Appl., 9 (23): 107-126.

Pickard, G.L. - 1971. Some physical oceanographic features of inlets of Chile. J. Fish. Res. Bd. Canada, 28: 1077-1106.

Pickard, G.L. - 1973. Water structure in Chilean fjords. In: R. Fraser (ed.), Oceanography of the south Pacific 1972, pp. 95-104. New Zealand Nat. Comm. for UNESCO, Wellington.

Reid, J.L. - 1994. On the total geostrophic circulation of the North Atlantic Ocean: flow patterns, tracers, and transports. Prog. Oceanog., 33: 1-92.

Saggiomo, V., A. Goffart, G.C. Carrada and J.H. Hecq. - 1994. Spatial patterns of phytoplankton pigments and primary production in a semi-enclosed periantarctic ecosystem: The Strait of Magellan. J. Mar. Syst., 5 (2): 119-142.

Sánchez, R.P., A. Remeslo, A. Madirolas and J. de Ciechomski. 1993. Distribution and abundance of post-larvae and juveniles of the Patagonian sprat, Sprattus fuegensis, and related hydrographic conditions. Fish. Res. (Netherlands), 23 (1-2): 47-81. 